IRA-International Journal of Applied Sciences ISSN 2455-4499; Vol.04, Issue 03 (2016)

Institute of Research Advances

Pg. no. 454-459

http://research-advances.org/index.php/IRAJAS

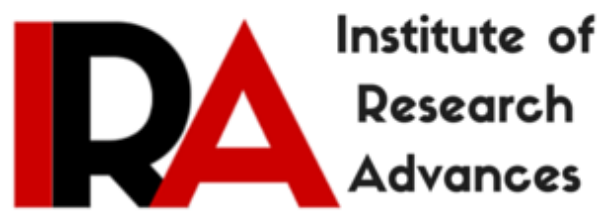

\title{
Chlorophycean Diversity of Selected Ponds in Etturnagaram Wildlife Sanctuary, Warangal District, Telangana, India
}

\section{Rev. Dr. J. W. Prakash}

Principal, Bishop Jesudasan Junior College, Etturnagaram, Warangal (Dist.), Telangana- 506165, India.

Type of Review: Peer Reviewed.

DOI: http://dx.doi.org/10.21013/jas.v4.n3.p9

\section{How to cite this paper:}

Prakash, J. (2016). Chlorophycean Diversity of Selected Ponds in Etturnagaram Wildlife Sanctuary, Warangal District, Telangana, India. IRA-International Journal of Applied Sciences (ISSN 2455-4499), 4(3), 454-459. doi:http://dx.doi.org/10.21013/jas.v4.n3.p9

(C) Institute of Research Advances

(c)) EY-NO

This work is licensed under a Creative Commons Attribution-Non Commercial 4.0 International License subject to proper citation to the publication source of the work.

Disclaimer: The scholarly papers as reviewed and published by the Institute of Research Advances (IRA) are the views and opinions of their respective authors and are not the views or opinions of the IRA. The IRA disclaims of any harm or loss caused due to the published content to any party. 


\section{ABSTRACT}

The present investigation was mainly aimed for to know the Chlorophycean diversity of selected ponds in Etturnagaram wildlife sanctuary, Warangal District of Telangana, India. The study was carried out for 6 months survey of Chlorophycean taxa, which deals with the planktonic, epithelic and benthic algae of ponds were studied. The total 38 taxa of Chlorophycean members have been recorded. This study was carried out during the months from 2015 December to May 2016.The samples were taken from five fixed ponds during the dry season of the year.

\section{Key Words}

Wildlife sanctuary, Ponds, Chlorophyceae, Diversity

\section{Introduction}

Indigenous fresh water systems are the hot spot of diverse and rare algal components as a result of varying micro habitats. Diversity in these localities is determined by habitat modification, harvest of native species and accidental introduction of exotic species. Algae, the principle primary producers, are photosynthetic thallophytes, usually microscopic, unicellular, and colonial or multi cellular organisms which perform the maximum quantum of photosynthetic activity than any living organisms in this world. Many forms spread throughout the water body and cause turbidity of water and algal blooms (Girish Kumar, 2014). Knowledge regarding the ecology of pond water is important tool for their systematic study (Ambili et al. 2015). The planktonic study is a very useful tool for the assessment of water quality and productivity of any type of water body and also contributes to understanding of lentic water bodies (Pawar et.al 2006). The maintenance of healthy aquatic ecosystem is dependent on the biological diversity of the ecosystem and the abiotic properties of water (Harikrishnan, et.al, 1999).

Algae are a large and diverse group of simple, typically autotrophic organisms, ranging from unicellular to multicellular forms (Casamatta et al., 1999). In aquatic ecosystems phytoplankton play an important role in the ecology of water bodies through primary production. Studies on planktonic composition are necessary to acquire basic knowledge on the biodiversity status of a water body. Algal flora varies from season to season and an important feature of freshwater algal flora is its cosmopolitanism. Latha and Ramachandra Mohan (2010), Leela et al., (2010), Ramadosu and Sivakumar (2010) and Chinnaiah et al., (2011) studied on various fresh water bodies and described different algal groups and is population.

\section{Materials and methods}

\section{Location}

Eturnagaram Wildlife Sanctuary is home to some scenic terrains, gorgeous tigers and rare species. Explore some interesting landscapes here. Eturnagaram Wildlife Sanctuary, located in the southern state of Andhra Pradesh, is a haven for wildlife enthusiasts and nature lovers from across the globe. The sanctuary is situated in Eturnagaram village of Warangal District and it is approximately 250 kilometers away from the capital city of Hyderabad. Sprawling across 806 square $\mathrm{km}$, this is one of the oft-visited and oldest sanctuaries in the country. Situated at a meeting point of the borders of Maharashtra, Andhra Pradesh and Madhya Pradesh, Eturnagaram Wildlife Sanctuary boasts of scenic terrains, undulating landscapes and a plethora of exotic species of flora and fauna. About 3/4ths of the area occupied by the sanctuary is plain land and the rest is defined by small hills, plateaus, springs and small streams. This protected region is flush with tropical forms of vegetation, dry deciduous trees, shrubs, herbs and plenty of grasses covering a major portion of its landscapes. The Eturnagaram Wildlife 
Sanctuary is also known for its tall trees like those of Teak, which shoot up to a height of 60 feet and more.

Dayyam Vagu is a perennial source of water in the Eturnagaram Wildlife Sanctuary. It divides the sanctuary into two halves and provides valuable resources for the animal and plant life within. Home to plenty of varieties of avian life, birds, fish, reptiles, animals and insects; Eturnagaram Wildlife Sanctuary has an important place in the eco-tourism map of India. (Map 1).

In the present work an attempt has been made to assess the Chlorophycean diversity of selected ponds in Etturnagaram wildlife sanctuary, Warangal District of Telangana, India. Comparative study of various stations of the ponds are unique. This type of study in this wildlife sanctuary is first time in the history. As the area of research is rich with various water resources, it is quite possible that there could be some difference in algal composition among the different ponds. The selected ponds are located in Bhuttaram (Station I), Royyur (Station II), Ettur (Station III), Santhigudem (Station IV) and Kannayigudem (Station V).

\section{Phytoplankton collection}

Phytoplankton samples were collected monthly from the four selected stations of the river for a period of six months, December 2015 to May 2016. The collections were made early in the morning by using a standard plankton net (No.25) with $30 \mathrm{~cm}$ mouth diameter and length of $1 \mathrm{~m}$. 100 liter of surface water was filtered and the filtrate was put into a clean labeled plastic containers. The volume of the concentrate was adjusted to $25 \mathrm{ml}$ and it was preserved immediately with $4 \%$ formalin for further analysis.

\section{Counting}

From the collected and concentrated filtrate $1 \mathrm{ml}$ of the sample was taken, after shaking the concentrate in order to get an even distribution of planktonic organisms for analysis. The analysis was repeated for 10 times and computed. The average number is expressed in per cubic / meter.

\section{Identification}

The collected microalgae were identified by using standard literatures (Desikachary, 1959; Prescott,1978; Anand, 1998). An artificial key was prepared after observing the important character of all forms collected and their systematic position is given below following Fritsch (1935) classification.

\section{Result and conclusion}

In the present investigation there are total 97 algal taxa belonging to 5 class's viz. Chlorphyceae, Bacillariophyceae, Cyanophyceae, Euglenophyceae and Xanthophyceae were found. In the class Clorophyceae mainly represented by the species of, Micrasterias, Oedogonium, Phytoconis,

Spirogyra, Scenedesmus, Pediastrum, Coleachaete, Bulbochaete, Chlorella. From this class 38 taxa of 32 genera of this class were recorded during the study period from various stations (Table 1). It would be obvious from present investigation that, the green algae, in the dominant members, diatoms and blue greens were the predominant members of phyto-cenose of this biotope of five ponds in the wildlife sanctuary.

\section{Acknowledgement}

Author would like to thank the friends who are along with us throughout the study. Especially I am thankful to the forest Department Etturnagaram, Bishop Dharmaraj Rassalam and Office bearers, Higher Education Society of C.S.I. South Kerala Diocese, Board for Mission, C.S.I. South Kerala Diocese, officers of Bishop Jesudasan Junior College, Dr.G.S.Regini Balasingh (Emirates scientist, 
Department of Botany and Research Centre, Scott Christian College, Nagercoil), Dr.L.B.S. Irence ,Dew Juswil, Reju Justin (Research Scholar, Department of Botany and Research Centre, Scott Christian College, Nagercoil), Jimry S. Kumar (Technical Assistant) and Justin Raj. J. T (Field Assistant) for their continuous encouragement and support to fulfill this primary research work

\section{Reference}

Ramadosu A and Siva Kumar K.2010. Seasonal variation of phytoplankton in relation to physicochemical characteristics at Perumal Lake, Tamilnadu. Indian Hydrobiology. 12(2):149-158.

Leela Bhosale, J,Patil S M,Sureka Dumal N and Anjaiah Sabale B.2010. Occurrence of Phytoplankton in the Lakes in and around Kolhapur city (Maharashtra). Indian Hydrobiology. 12(2):133-142.

Chinnaiah B Ramesh Babu M and B.Digamber Rao.2011.Phycoplankton diversity and population dynamics of Ramappa Lake, (A.P) India.Ad.Plant.Sci.24 (II):527-529.

Sivakumar, K.,Senthilkumar,R. 2008. Studies on phytoplankton diversity in response to abiotic factors InVeeranam Lake in the Cuddalore district of Tamil Nadu., Journal of Environmental Biology September 2010, 29(5) 747-752

Desikachary, T.V. (1959). Cyanophyta, New Delhi, India. 686.

Prescott, G.w. (1978). How to know Freshwater Algae 3 rd Edn. Wes. C. Brown Company Publication, Iwona, USA - $1-280$ pp.

Anand, N. (1998). Indian freshwater microalgae. Bishen Singh Mahindra Pal Singh (Publisher). Dehradun. Pp. 22-98.

Harikrishnan, K. Sabu, G. Sanil, M. Paul, M. Satish and M.R. Das, "A study on the distribution and ecology of phytoplankton in the Kultanad wetland ecosystem", Kerala. Pollut. Res, Vol. 18, pp. 261-269, 1999.

Pawar, S.K. J.S. Pulle and K.M. Shendge, "The study on phytoplankton of Pethwadaj Dam, Taluka Kandhar, District-Nanded,Maharashtra”, J. Aqua. Biol, Vol.21, pp.1-6,2006

Ambili Nath , Neethu R.V and Revathy J.S :Diversity of Plankton in a Village Pond at Dhanuvachapuram, Trivandrum International Journal of Innovative Research in Science, Engineering and Technology: Vol. 4, Issue 9, September 2015.

Girish Kumar E, Rekha C., Pradeep Kumar G., Sasikala K. and Sivadasan K.K Diversity Of Planktonic Algae Of Selected Temple Ponds Of Mahe (U.T. of Puducherry), India: International Science Journal Volume- 1 Issue-3 (2014) 
Table 1. List of Chlorophycean Algae Found in Different Ponds of Etturnagaram Wildife Sanctuary

\begin{tabular}{|c|c|c|c|c|c|}
\hline Name of the algae & \begin{tabular}{|l} 
Station \\
I
\end{tabular} & $\begin{array}{l}\text { Station } \\
\text { II }\end{array}$ & $\begin{array}{l}\text { Station } \\
\text { III }\end{array}$ & $\begin{array}{l}\text { Station } \\
\text { IV }\end{array}$ & $\begin{array}{l}\text { Station } \\
\text { V }\end{array}$ \\
\hline Arthrodesmus fuellebornes, schm & + & + & + & - & + \\
\hline Botryococcus bracinii Kuetz & + & + & + & + & - \\
\hline Bulbochaete insignis, pringsh & - & + & - & + & - \\
\hline Chlorella vulgaris, Beij & - & + & - & + & + \\
\hline Chloroccum humicolo (Naeg) Raben & + & - & + & + & - \\
\hline Coelastrum microporum, Beyne & - & + & - & - & - \\
\hline Cosmarium botrytis (Menegh) & - & + & - & - & + \\
\hline Coleochate soluta $(\mathrm{Breh})$ & - & - & - & + & - \\
\hline Closterium moniliferum (Bory)Ehrenb & + & - & + & + & + \\
\hline Closterium ceratium (perty) & + & + & + & - & - \\
\hline Chlamydomonas gigas, Fritsch & + & - & + & - & + \\
\hline Crucigenia lauterbornei & + & + & + & + & - \\
\hline Desmidium grevilli (Kuetz) & + & + & + & & + \\
\hline Euastrum spinulosum (Delponte) & + & + & + & + & + \\
\hline Hyalotheca тисова (Dill) & - & + & - & - & - \\
\hline Kirchnerilla lunaris (Kirch) Moebius & - & - & + & - & + \\
\hline Micrasterias malabuleshwarensis & + & - & - & - & + \\
\hline Mesotaenium macrococcum (Kuetz) Ray. & - & - & - & + & - \\
\hline Oedogonium echinospermum & - & + & + & - & + \\
\hline Oocystis elliptica (west \& west) & + & + & + & - & - \\
\hline Pithophora mooreana (cellins) & + & + & + & + & - \\
\hline Penium borgeanum (Skiya) & + & + & + & + & + \\
\hline Pediastrum duplex, meyan & - & - & - & + & + \\
\hline Pediastrum tetras (Her; Rarrs) & - & + & - & - & + \\
\hline Pleurotaenium verucosum (Ball) Lund & + & + & + & + & - \\
\hline Rhizoclonium hieroglyphiarum (west) & + & - & - & - & - \\
\hline Scenedesmus quadricauda (Jerpin; Brob) & + & - & - & - & + \\
\hline Staurastrum setigerum (Nordst) & + & + & + & + & - \\
\hline Stigeoclonium tennue (Rabenb) & + & + & + & + & - \\
\hline Tetraedron regulare, (pres) & - & + & + & + & + \\
\hline Tetraspora gelatinosa, vauch, Desvaur & - & + & - & + & + \\
\hline Thamniochaete huberi (Gay) & + & - & + & + & + \\
\hline Ulothrix zonata (weber et Mohr, kuetz) & - & - & + & + & - \\
\hline Zygnema pectinatum, Rao & + & - & - & + & + \\
\hline Spirogyra decimina (Kuetz) & + & - & + & - & - \\
\hline Staurastrum setigerum (Nordst) & + & - & - & - & - \\
\hline
\end{tabular}

+ Present

- Absent 
Map 1. Showing the research location

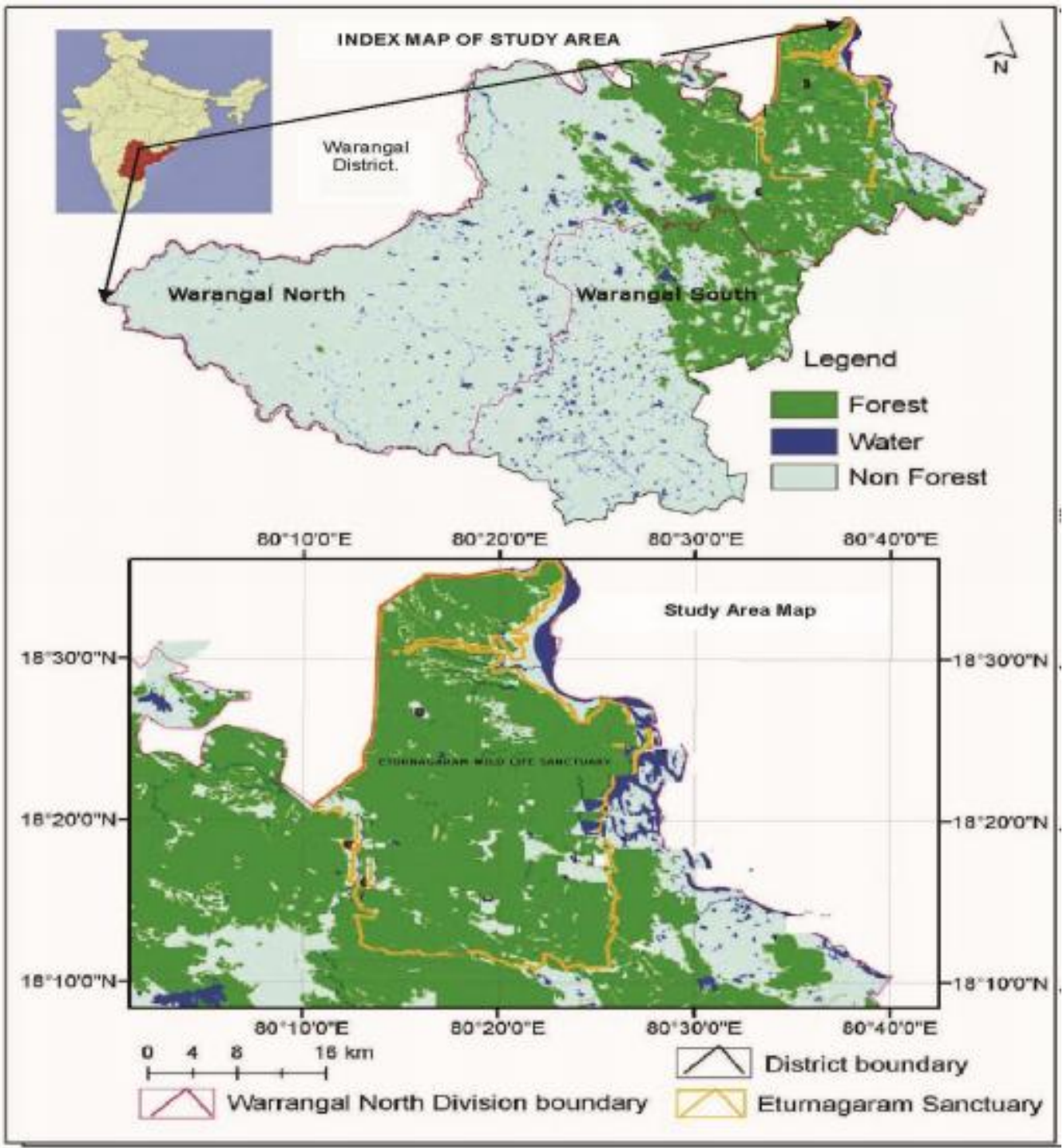

